\title{
ВАСНЕЦОВСКИЙ СЛЕД НА ИГРИНСКОЙ ЗЕМЛЕ: СОЦИОКУЛЬТУРНЫЙ АНАЛИЗ
}

\section{VASNETSOV IGRINSKAYA MARK ON THE LAND: A SOCIO-CULTURAL ANALYSIS \\ E. Shcherbakova}

Summary: The article examines how the history and culture of the small Motherland are preserved in the scale of one rural Igrinsky district of the Udmurt Republic in the conditions of multi-ethnicity of its population, distributed among small villages and villages. How to solve spiritual and moral problems of modern society through the implementation of projects: "Vasnetsovo multicolored" and "Vasnetsovo symbols of eternity", the essence of which is to promote the heritage of the talented Vasnetsov family, whose clergy served in Udmurtia. The result of the projects is shown-a spiritual ascent based on the symbols of art and Orthodox values.

Keywords: art, culture, heritage, Orthodox values, race, homeland, family, priest.

\author{
Щербакова Елена Николаевна \\ Преподаватель, Краснодарское высшее военное училище \\ имени генерала армии С.М. Штеменко \\ Sherbakova120559@mail.ru
}

Аннотация: В статье рассматривается, как в масштабах одного сельского Игринского района Удмуртской республики (бывшая Вятская губерния) в условиях полиэтничности его населения, распределенного по небольшим деревням и селам, сохраняются история и культура малой родины. Как решаются духовно-нравственные проблемы современного общества через реализацию проектов: «Васнецовское разноцветье» и «Васнецовские символы вечности», суть которых - популяризация наследия талантливого рода Васнецовых, священнослужители из которого служили в Удмуртии. Показан итог проектов - духовный подъем на символах искусства и православных ценностях.

Ключевые слова: искусство, культура, наследие, православные ценности, род, малая родина, семья, священник.

родился 4 февраля 1867 года в селе Сезенево Слободского уезда, в семье священника Васнецова Федора Гавриловича (1822-1905). В 1887 году окончил Сарапульское уездное училище. Духовное служение начал учителем в селе Русская Лоза в 1894 году. В том же году определен псаломщиком к Чумойской церкви Сарапульского уезда. Николай Федорович сразу включается в обучение служительских и крестьянских детей, становится учителем организованной церковно-приходской школы. В 1905 году посвящен в сан дьякона с оставлением на том же месте. В 1907 году, согласно прошению, перемещен в село Зуру Глазовского уезда. Педагогическую ниву он и после перевода к Митрофановской церкви не оставил. С 1910 года допущен Уездным Отделением к преподаванию Закона Божьего в Зуринской церковно-приходской школе, а с 1913 года - в Квадровозском земском училище. Известно, что он понимал разговорную речь удмуртов и сам немного говорил на их языке.

Его отец, Федор Гаврилович Васнецов (1828-1901), из духовного сословия, родом из Вятского уезда Вятской губернии. После окончания Вятской духовной семинарии с аттестатом второго разряда около двадцати лет прослужил священником в Тихвинско-Богородицкой церкви села Паздеры Сарапульского уезда, имеет канонические и литургические награды (набедренник, скуфья) и многочисленные духовные поощрения. Именно с села Паздеры, откуда берет свое начало священнический путь на Удмуртской земле Ф.Г. Васнецова, начинается

Васнецов Николай Федорович, священнослужитель, 
изучение генеалогического древа Васнецовых на Игринскогй земле.

Мать, Александра Павловна (1830 г.р.), из духовной семьи, родом из Вятского уезда Вятской губернии, получила домашнее начальное образование. В разных документах встречается отчество разное: Павловна, Анисимовна, Петровна.

В их семье было пятеро детей: Илья (1895 г.р.), Михаил (1860 г.р.), Клавдия (1864 г.р.), Николай (1867-1941), Владимир (1871-1901). Все сыновья получили духовное образование в Сарапульском уездном училище, содержание которого ложилось на приходы: церковь обязана была делать денежное отчисление, следовательно, считать обучение бесплатным можно лишь относительно. А так как семья была многодетная, то и учить детей пришлось всех сразу. Поэтому Сарапульское уездное училище Николай Васнецов окончил только в 1887 году (к двадцати годам) и был направлен учителем в село Русская Лоза. Будучи учителем, он знакомится с Юлией Никаноровной Шкляевой, дочерью дьякона села Чутыря. Выбор священнического служения Николай Федорович делает осознанный, поскольку он женится одновременно с определением его псаломщиком в село Чумой.

В семье Васнецовых Николая Федоровича и Юлии Никаноровны родилось шестеро детей: Василий (18951915), Агния (1896-1899), Мария (1899-1983), Серафима (1901-1902), Людмила (1903 г.р.), Капитолина (1905 г.р.). Родители прикладывали все усилия к тому, чтобы дети получили образование.

Сын, Василий, получив начальное образование в Чумойской церковно-приходской школе, обучался в Сарапульском духовном училище на подготовительном отделении, в Глазовском духовном училище, Балезинском двухклассном училище, Сосновской двухклассной учительской школе. Затем состоял церковником при церкви Трудолюбия в г. Вятке. Когда началась Первая мировая война, Василий был призван в ряды действующей армии, а 16/23 сентября 1917 года погиб. Похоронен в церковной ограде Митрофановской церкви села Зуры.

Дочь, Мария, в 1916 году окончила Вятское епархиальное женское училище. В 1921 году венчалась с Кузнецовым Алексеем Васильевичем (1898-1949), начальником почты, воспитала троих сыновей: Николая (1922-2008), Виктора (1925-1991), Василия (1927-2007). Посвятила всю жизнь учительскому труду. Имеет правительственные награды: орден Ленина, медаль «За доблестный труд в Великой Отечественной войне 19411945 гг.», ветеран саракташской средней школы. Похоронена на краснодарском военном почетном кладбище.

Младшая дочь, Людмила, в 1915 году поступила в
Вятское епархиальное училище. В 1916 году закончила первый класс первого отделения, но окончить училище из-за его упразднения ей не удалось.

Не посчастливилось учиться в этом училище и самой младшей дочери, Капитолине.

О том, как сложились судьбы Людмилы и Капитолины неизвестно.

В селе Чумое семья Васнецовых Николая Федоровича и Юлии Никаноровны прожила тринадцать лет, с июля 1894 года по май 1907 года. Жили в новом доме, построенном на церковной земле.

За период тринадцатилетней жизни в селе Чумое псаломщику Николаю Федоровичу Васнецову пришлось служить со многими священниками. Послужные характеристики всех священников безупречны. На их счету многочисленные проповеди собственного сочинения. Все исполняли должности заведующих и законоучителей Чумойской церковно-приходской школы, имеют первые награды, благодарности. Практически одного возраста, все семейные, с пониманием вотского языка и знанием фраз разговорного языка. Ревностные сторонники образования и просвещения, развития культуры в своем приходе. Отсутствие дел по различного рода спорам, ссорам, недоразумениям, оскорблениям и проступкам свидетельствует о благоприятном психологическом климате в приходе между членами причта и причта с прихожанами.

Обживаясь в селе Чумое, обучая детей, выполняя обязанности псаломщика, а затем дьякона, деля все тяготы жизни с прихожанами, тесно общаясь с меняющими друг друга священниками, помогая последним быстрее адаптироваться к новым условиям, к новому месту, Николай Федорович приобретал авторитет среди прихожан, их доверие и поддержку. Люди, обретая веру, тянулись в церковь. Церковь становилась центром жизни прихода. Росло материальное благосостояние церкви и причта.

В жизни семьи Васнецовых были свои радости, но была и боль горьких утрат: смерть отца Юлии Никаноровны, смерть отца Николая Федоровича. Гораздо более тяжелой утратой стала смерть дочерей: Агнии и Серафимы.

Таким образом, начало нового столетия для семьи, с одной стороны, складывалось благополучно: посвящение отца, Николая Федоровича, в сан дьякона, относительное материальное благополучие, уважение прихожан, стабильность жизни; с другой - цепь трагических событий.

В мае 1907 года Николай Федорович Васнецов пода- 
ет прошение о переводе в село Зуру. 22 мая 1907 года, согласно прошению, Николай Федорович перемещен к Митрофановской церкви села Зуры. Семья Васнецовых поселилась в церковном доме, построенном для причта на церковной земле. Недвижимого имущества у семьи по-прежнему не было. Хотя и материальный доход семьи вырос, но объем работ возрос.

Педагогическую ниву он и после перевода к Митрофановской церкви не оставил. Сначала преподавал Закон Божий в Зуринской церковно-приходской школе, а затем и в Квадровозском земском училище.

Семья Васнецовых проживала в Зуре до июля 1927 года.

На сегодняшний день неизвестно, как сложилась дальнейшая судьба Васнецовых Николая Федоровича и Юлии Никаноровны.

В истории Игринского района есть еще след Васнецовых:

Алексей Алексеевич Васнецов - с 1906 по 1912 гг. работал начальником Зуринского почтового отделения. Чина не имел, но свой след в истории развитии почтового дела на Игринской земле оставил. Тоже выходец из священнической династии Васнецовых.

Псаломщик Михаил Иванович Васнецов - с 1889 по 1892 гг. служил в селе Зуре, умер 25 сентября 1898 года.

Вышедший из народа, не потерявший связи с народом представитель династии Васнецовых, Николай Федорович Васнецов, вступил на путь священничества по призванию, по велению души. Он заботился о посильном христианском просвещении, грамотности людей, оказывал врачебную помощь советом и делом, знакомил крестьян с усовершенствованными способами ведения сельского хозяйства, по пчеловодству, огородничеству, садоводству, земледелию.

Николай Федорович не имел глубокого богословского образования, его священнический путь был тернистым, основанным на его исключительном трудолюбии и усердии, стремлении к знаниям. И своих, и крестьянских детей наставлял к получению образования либо в богословских, либо в светских учебных заведениях. Николай Федорович не лишен был певческого дарования [3].

Как и все представители священнической династии Васнецовых Николай Федорович делил с народом все тяготы жизни. И даже в годы революционной стихии, начавшейся братоубийственной войны, когда падала религиозность, нравственность, когда замечалось охлаждение к Вере, когда материальное существование духовенства становилось все ничтожнее, он прикладывал все свои усилия к тому, чтобы не допустить невнятного, невыразительного чтения, чтобы с великим терпением выстоять церковную службу и поддержать в себе и в прихожанах молитвенное настроение, что не может не вызывать нашей благодарной памяти о нем и о роде. И сейчас, когда в обществе возникает опасность утраты духовных идеалов, мы обращаемся к духовному завещанию, оставленному талантливым родом Васнецовых.

Род Васнецовых оставил духовное завещание потомкам через культурное наследие, ставшее символом национальной идентификации. Сегодня интерес к классическому наследию угас. Массовая культура заполнила все пространство. Настоящее искусство, как говорят профессионалы, становится делом дилетантов. В условиях подмены истинных ценностей на «глянец» ослаб и духовный стержень у населения Игринского района. К тому же территория Удмуртии особо пострадала в годы гонений на Церковь. Как следствие - многоликий сельский кризис. В «древе» проблем - инвалидизация населения, которая создает нагрузку на органы соцзащиты, гражданский ресурс поддержки инвалидов ослаб. Другая проблема: истощается культурный пласт, таланты и способности не востребованы. Более перспективная молодежь уезжает, не видя применения способностям. Все меньше детей занимается творчеством, да и мастера становятся редкостью, скоро некому будет передавать опыт. Главная причина этих проблем - принятие ценностей «общества потребления», утрата родовой памяти, «зазор» между поколениями [6].

В целях решения данных проблем в районе были реализованы проекты, суть которых - популяризация наследия рода Васнецовых, священнослужители из которого служили в Удмуртии. Эпицентром проектов стало село Чумой, где на десятилетие обрел родину священнослужитель Н. Ф. Васнецов.

Так, к 340-му юбилею села Чумоя, который отмечался в июне 2018 года, был реализован проект «Васнецовское разноцветье», посвященный восстановлению родника в селе, сохранению старинных Васнецовских лип, растущих в бывшей усадьбе священников, посадке новой липовой аллеи, созданию местного памятника природы.

В год же празднования ста семидесятилетия великого русского художника Виктора Михайловича Васнецова (1848-1926) был реализован проект «Васнецовские символы вечности», получивший грант международного конкурса «Православная инициатива - 2017-2018» по благословению Святейшего Патриарха Московского и всея Руси Кирилла.

Цель проекта - популяризация наследия талантливого рода Васнецовых, представители которого служили 
в храмах Удмуртии, была достигнута через несколько проектных линий. Первая линия - реабилитация детей и взрослых с ограниченными возможностями здоровья средствами культуры и искусства. Вторая - развитие творческих способностей учащихся общеобразовательных школ и школ искусств, их преподавателей, мастеров декоративно-прикладного искусства путем вовлечения в круг мероприятий Васнецовской тематики. Третья линия - благоустройство природных уголков в поселке Игре и селе Чумое.

Были проведены арт-терапевтические занятия для людей с ограниченными возможностями.

Комплексы традиционных форм работы дополняли инновационные. Например, конференция «на колесах» под названием «Не зарастет тропинка к храму». Мероприятие было организовано в форме «духовных кругов», которые прошли в селах, где Н.Ф. Васнецов служил псаломщиком и дьяконом в православных храмах: Святителя Митрофана Воронежского села Зуры, Богоявления
Господня села Чумоя и Иоанна Предтечи села Русская Лоза. Участники конференции «на колесах» совершили экскурсии в храмы, познакомились с их историей, приобщились к православной культуре, почувствовали гостеприимство местных жителей.

Были использованы и другие, не менее интересные, инновационные формы: инклюзивная арт-терапия, театр-антреприза, создание арт-объектов, арт-зон, пленэр. Итог - духовный подъем на символах искусства и православных ценностях.

Таким образом, главный результат реализованных в районе проектов - воодушевление местных жителей теми вековечными ценностями, которые, оказывается, находятся рядом и в повседневности будней не всегда оценимы. Произошло духовное прозрение, просветление сознания жителей Игринского района. И это серьезный результат проектов «Васнецовское разноцветье» и «Васнецовские символы вечности», повлиявших на формирование национальной идентификации.

\section{ЛИТЕРАТУРА}

1. Электронный ресурс]. URL: vasnetsov.foundation (дата обращения 12.03.2020).

2. Васнецовы. Предки и потомки - переплетение судеб: сб. / МБВК «Игоинская ЦБС», Игринская центраьная районная библиотека им. Кедра Митрея; сост. Н.В. Дубовцева; техн. ред. А.В. Хохрякова. - Игра, 2017. - 52 с. : фот.

3. Васнецовы и Шкляевы на Игринской земле / МБУК «Игринская централизованная библиотечная система»; составитель Е.3. Абрамович; компьютерная верстка Н.В. Дубовцева; обложка, технический редактор А.В. Хохрякова. - Игра, поселок (Удмуртская Республика): Игринская центральная районная библиотека, 2020. - стр. : фот. ; 21 см.

4. Гордеюк В.Г., Скопкарева С.Л. Васнецовы на Игринской земле: научное издание. Ижевск, 2018.

5. Дубовцева Н.В. Чумой украсили Кедрами. // Светлый путь. 2018. № 41 (9771).

6. Иднакар: методы историко-культурной реконструкции [Текст]: научно-практ. журн.: Васнецовский альманах / МБУК «Игринская ЦБС®. - 2018. - № 2 (37). -162 с.: ил.

○ Щербакова Елена Николаевна (Sherbakova120559@mail.ru). 